\title{
Light-related variation in sapling architecture of three shade-tolerant tree species of the Mexican rain forest
}

\author{
Variación arquitectural de árboles juveniles en relación con la luz en tres especies toleran- \\ tes a la sombra en una selva húmeda mexicana
}

JOSÉ LUIS MARTÍNEZ-SÁNCHEZ ${ }^{*}$, JORGE A. MEAVE² \& FRANS BONGERS ${ }^{3}$

\author{
${ }^{1}$ División Académica de Ciencias Biológicas, Universidad Juárez Autónoma de Tabasco, kilómetro 0,5, \\ Villahermosa-Cárdenas, Villahermosa, Tabasco, 86990, México \\ ${ }^{2}$ Departamento de Ecología y Recursos Naturales, Facultad de Ciencias, Universidad Nacional Autónoma \\ de México, 04510, Distrito Federal, México \\ ${ }^{3}$ Centre for Ecosystems Studies, Forest Ecology and Forest Management group, Wageningen Agricultural University, \\ PB 6708 AH Wageningen, The Netherlands; \\ *email for correspondence: jlmart@cicea.ujat.mx
}

\begin{abstract}
The crown architecture of three shade-tolerant tree species (two subcanopy and one mid-canopy) was analyzed in relation to the light regime of the forest understorey. The aim was to examine to which extent shade-tolerant species variate in their crown architecture. Tree saplings (265) between 50 and $300 \mathrm{~cm}$ height, and distributed from understorey to variously-sized canopy gaps, were measured for 13 architectural traits in the lowland rain forest of Los Tuxtlas, México. The analysis showed that the three species changed their architecture as light increased but in a different way. No species conformed to the typical wide-crown type expected for shade-tolerant species, and in contrast they presented some traits of light demanding species. The two sub-canopy species tended to adopt a crown form between a narrow- and wide-crown type, and the midcanopy species showed more traits of a narrow-crown type. The horizontal crown area appeared as the more related trait to the light and sapling height. It is concluded that despite being shade-tolerant, the studied species make use of better-lit environments in the forest understorey. The crown architecture of shade-tolerant species is not as rigid as originally conceived.
\end{abstract}

Key words: actinometry, allometry, growth type, phenotypic plasticity, tree morphology.

\section{RESUMEN}

Se analizó la arquitectura de la copa de tres especies tolerantes a la sombra (dos del sotobosque y una del dosel medio) en relación con el ambiente lumínico del sotobosque de la selva. El objetivo fue examinar el grado de variación que presenta la arquitectura de la copa de especies tolerantes a la sombra. Para esto, se midieron 13 variables arquitecturales en 265 árboles juveniles $(50-300 \mathrm{~cm}$ de altura) distribuidos desde sitios de selva madura hasta claros de diversos tamaños, en la selva húmeda tropical de Los Tuxtlas, México. El análisis mostró que las tres especies cambian la arquitectura de su copa a medida que aumenta la disponibilidad de luz, pero de diferente forma. Ninguna especie presentó el típico modelo de copa plana esperado para las especies tolerantes a la sombra. Las dos especies del sotobosque tendieron a adoptar una copa intermedia entre plana y alargada, mientras que la especie del dosel medio, tendió hacia una copa alargada. El área horizontal de la copa se mostró como la variable más relacionada con la luz y altura del árbol. Se concluye que a pesar de ser especies tolerantes a la sombra, aprovechan los ambientes más luminosos para su desarrollo. La arquitectura de copa de las especies tolerantes a la sombra no es tan rígida como se creía en un principio.

Palabras clave: actinometría, alometría, forma de crecimiento, morfología arbórea, plasticidad fenotípica.

\section{INTRODUCTION}

Light interception is one of the major factors controlling total carbon assimilation and tree growth (Hilbert \& Messier 1996), and it is influenced by forest canopy characteristics as well as by architectural traits of trees such as crown shape, inter-branch spacing, and leaf morphology (Horn 1971, Givnish 1988, King 1990). In a tropical rain forest there is a substantial spatial and temporal variation in irradiance at the forest floor (Chazdon \& 
Fetcher 1984). Phenotypic plasticity exists at the photosynthetic level, branching patterns and biomass allocation, all of which enables the saplings of a given tree species to occupy different microenvironments within the forest (King 1994). Light also affects three main morphological traits of the tropical tree crown: total leaf area and leaf self-shading (leaf spread), which in turn influence crown size. For successful growth and survival, saplings need to spread their leaves to reduce selfshading. Leaf spreading may be horizontal to avoid mutual shading of a mainly vertical light source (Warren Wilson 1981), or vertical to reduce lateral penumbra effects (Terborgh 1985, Clearwater \& Gould 1995). Spreading of leaves in any direction, affects crown size.

In tropical rain forests pioneer and shadetolerant species coexist because they partition the forest light gradient. Species have contrasting growth strategies like pioneer species which complete their life in the forest gaps, and shade-tolerant species that are able to survive in the shade (Martínez-Ramos 1985). Sapling architecture has been observed to differ between these two groups of species (Kohyama 1987, 1991, Kohyama \& Hotta 1990, King 1991, 1994, Turner et al. 1995, King et al. 1997, Bongers \& Sterck 1998). Pioneer species have a narrow crown to enhance vertical height growth and out-compete their neighbors, and shade-tolerant species have wide crown to enhance current light interception (Kohyama 1987), shorter and thicker trunks to support their heavier crown and perhaps be more resistant against falling branches (Küppers 1989), and wider but less deep crowns.

Many studies have examined sapling architecture along the light gradient of the understorey, finding a higher level of crown plasticity in the pioneer species (King 1991, 1994, King et al. 1997, Bongers \& Sterck 1998, Poorter 1999, Poorter \& Werger 1999, Sterck et al. 1999). However, Poorter \& Werger (1999) and Sterck et al. (2003) particularly found a sort level of plasticity in the crown architecture of shade-tolerant species. King (1994) found considerable morphological plasticity in shadetolerant species, with sun plants having faster stem growth rates and a larger biomass allocation to leaves, than plants growing in the shade. Alves \& Santos (2002) found some architectural plasticity in subcanopy species, which transit from shade to a more illuminated environment along their lives.

In the present study we analyze the variability in sapling architecture of three shade-tolerant species in relation to the light regime. We addressed two main questions: (1) is architectural variation in shade-tolerant species related to the light environment?, and (2) how does crown architecture relate to the light environment in these shade-tolerant species? To answer these questions, two subcanopy species (more shade-tolerant) and one mid-canopy tree species (less shadetolerant) were chosen.

\section{MATERIAL AND METHODS}

The study was conducted at the "Los Tuxtlas" Biological Station (Universidad Nacional Autónoma de México) located in SE Veracruz State, México (18 $34^{\circ}-18^{\circ} 36^{\prime} \mathrm{N}, 95^{\circ} 04^{\prime}-95^{\circ} 09^{\prime}$ $\mathrm{W})$. The climate is warm and humid; mean annual temperature is $25.1{ }^{\circ} \mathrm{C}$ and mean annual precipitation is 4,487 $\mathrm{mm}$ (Martínez-Sánchez 1999). From November through February, there is a high incidence of strong, cool and humid winds from the north locally called "nortes", which reach velocities up to $80 \mathrm{~km} \mathrm{~h}^{-1}$. They play an important role in the dynamics of this forest as they recurrently create canopy openings by causing the fall of trees and branches (Martínez-Ramos 1985). A detailed description of the forest structure was published elsewhere (Bongers et al. 1988, Popma et al. 1988). The forest is a lowland tropical rain forest, characterized by a relatively low stem density $(2,976$ individuals with $\mathrm{dbh} \geq 1 \mathrm{~cm}$, and 346 individuals $\mathrm{dbh} \geq 10$ $\left.\mathrm{cm} \mathrm{ha}{ }^{-1}\right)$. In a 1-ha plot, 234 species $(\geq 0.5 \mathrm{~m}$ height) were recorded from which $55.1 \%$ were trees, $9.4 \%$ shrubs, $3.4 \%$ palms, $20.1 \%$ vines, $6.8 \%$ herbs, and $5.1 \%$ of unknown life-form. Canopy strata cannot be clearly distinguished (Popma et al. 1988); however, the palm Astrocaryum mexicanum clearly dominates the understorey (up to $10 \mathrm{~m}$ ), and the tree Pseudolmedia oxyphyllaria dominates a middle storey or subcanopy. At 30-35 m high a closed continuous canopy occurs.

Three tree species widely distributed in the different microenvironments were selected. (1) Guamia sp. ("colorado") with heights about 3-7 
$(-10) \mathrm{m}$, an as yet undetermined and perhaps undescribed understorey species of the Annonaceae family, which was earlier erroneously reported as Sapranthus microcarpus (Donn.Sm.) R.E.Fr. (Murray 1993). (2) Pseudolmedia oxyphyllaria Donn.Sm. ("tomatillo") a moraceous midcanopy species reaching heights of 20-25 (-30) $\mathrm{m}$ and dbh of $30-50 \mathrm{~cm}$. (3) Trophis mexicana (Liebm.) Bur. ("ramoncillo"), an understorey species also in the Moraceae; 5-7 (-12) m height (Ibarra-Manríquez \& Sinaca-Colín 1995, 1996). Guamia, P. oxyphyllaria and $T$. mexicana have simple alternate leaves, $5-15 \mathrm{~cm}$ in length. The three species exhibit orthrotopic and monopodial growth in the trunk, and plagiotropic and monopodial growth in the branches. At the sapling stage all three species are capable of surviving and growing in the shade. For the sake of brevity, hereafter these species will be referred to only by the generic name.

For all species, individuals measuring between 50 and $300 \mathrm{~cm}$ in height and without apparent physical damage were selected: 88 for Guamia, 100 for Pseudolmedia, and 87 for Trophis. Only four individuals over $250 \mathrm{~cm}$ of Guamia were selected which may not be adult trees. For each individual 13 architectural variables were measured (Table 1), related to the light interception and support.

\section{Light environment}

Light availability was estimated for each individual using an actinometric method. Actinometry is defined as the amount of light absorbed by a chemical solution (Borrel 1980). The application of actinometry in ecology goes back to 1957 and 1959 by Maas and Westhoff, respectively (Pierik 1965). Anthracene $\left(\mathrm{C}_{6} \mathrm{H}_{4}\right.$ : $\left.(\mathrm{CH})_{2}: \mathrm{C}_{6} \mathrm{H}_{4}\right)$ is one of the most commonly used compounds in actinometry. As a direct function of the number of absorbed light moles, two molecules of anthracene combine and form dianthracene (Pierik 1965). Anthracene absorbtion is almost completely confined to the UV spectrum, which is not useful for photosynthesis. Up to date, actinometry has not been used in plant ecology yet and there are no published works on this topic, however a previous assay using a $1 \mathrm{~m}$ Licor photometer showed that UV extinction through the forest canopy is directly proportional to the extinction of photosynthetically active radiation (PAR; Bongers \& Popma unpublished data). Thus, anthracene may be reliably used to evaluate PAR availability for plants.

TABLE 1

List of architectural variables used in the analysis

Lista de las variables arquitecturales usadas en el análisis

\begin{tabular}{|c|c|c|c|}
\hline Symbol & Variable & Unit & Description \\
\hline $\mathrm{H}$ & Sapling height & $\mathrm{cm}$ & Sapling height from the ground to the top \\
\hline $\mathrm{D}$ & Stem diameter & $\mathrm{cm}$ & Stem diameter measured at $30 \mathrm{~cm}$ height from the ground \\
\hline $\mathrm{LN}$ & Number of leaves & - & Leaves longer than $3 \mathrm{~cm}$ \\
\hline $\mathrm{HCA}$ & Horizontal crown area & $\mathrm{cm}^{2}$ & $\begin{array}{l}\text { Estimated with the two cross-section diameters of the crown and } \\
\text { calculated as an ellipse }(0.25 \pi * \mathrm{D} 1 * \mathrm{D} 2) \text { (Bongers et al. 1988) }\end{array}$ \\
\hline VCA & Vertical crown area & $\mathrm{cm}^{2}$ & Estimated as an ellipse $(0.25 \pi *(\mathrm{D} 1+\mathrm{D} 2 / 2) * \mathrm{CD})($ Sterck et al. 2003) \\
\hline BL & Branch length & $\mathrm{cm}$ & $\begin{array}{l}\text { Length of the main branches along the stem. The mean value of all } \\
\text { branches was used. }\end{array}$ \\
\hline IBD & Inter-branch distance & $\mathrm{cm}$ & $\begin{array}{l}\text { Distance between two main branches along the stem. The mean value } \\
\text { was used. }\end{array}$ \\
\hline $\mathrm{CD}$ & Crown depth & $\mathrm{cm}$ & Distance from the botton-most branch to the top of the sapling \\
\hline $\mathrm{TS}$ & Trunk slenderness & - & $\mathrm{H} / \mathrm{D}$ \\
\hline $\mathrm{CS}$ & Crown slenderness & - & $\mathrm{HCA} / \mathrm{CD}$ \\
\hline CLS & Cost of leaf support & - & $\mathrm{BL} / \mathrm{LN}$ \\
\hline HS & Horizontal crown self-shading & - & $\mathrm{LN} / \mathrm{HCA}$ \\
\hline VS & Vertical crown self-shading & - & LN/VCA \\
\hline
\end{tabular}


Benzene was used as a solvent for anthracene (however, it is possible to use a less carcinogenic solvent like ethanol). The readings of the anthracene concentrations $\left(0.06 \mathrm{~g} \mathrm{~L}^{-1}\right)$ were done at a $370 \mathrm{~nm}$ wavelength with a spectrophotometer (Bausch-Louds Spectronic 21) before and after exposure to light. To expose the anthracene solution to light in the field, 17$\mathrm{mL}$ test tubes were used. One tube was placed per individual, using wires strategically attached previously to the plants, so that they minimized obstructions to light by any branch or leaf of the same individual and received the largest possible amount of direct and diffuse light. The solution was exposed during three days for each species (a total of 32-34 light hours), placing the tubes just after sunrise on the first day and removing them just before sunset on the third day. Control tubes were located outside the forest and total radiation was measured with the photometer of total light readings, calibrated in $\mathrm{mol} \mathrm{s}^{-1} \mathrm{~m}^{-2}$. The precision of the actinometric method was tested at 30 points of the forest along the whole light gradient, from deep shade through gaps, to open sites. Light availability was measured directly at each point with the photometer and two tubes were placed for 7-10 h. After exposure to light, all tubes were refrigerated at ca. $5-7{ }^{\circ} \mathrm{C}$ in order to keep the reversion of dianthracene to anthracene to a minimum. During the three days of exposure to light, total radiation in the open was $16.7 \mathrm{~mol} \mathrm{~m}^{-2} \mathrm{~d}^{-1}$ for Pseudolmedia, and 17.5 mol m $\mathrm{m}^{-2} \mathrm{~d}^{-1}$ for Guamia and Trophis. The percentage of the total light above the canopy was used for each individual. Absorbance values of zero obtained in sites with deep shade indicate that exposure time of the anthracene solution was insufficient in this poorly-lit environment. Correlation coefficient $(r)$ between the actinometric method and PAR (moles $\left.\mathrm{m}^{-2} \mathrm{~s}^{-1}\right)$ from the photometer was $0.92(n=30)$.

\section{Statistical analysis}

In tree saplings, there is a strong correlation between sapling height and crown architecture (Kohyama 1987, King 1990) such that sapling height influences any analysis of environment and sapling architecture relationship. A multiple regression analysis was chosen to separate the effects of sapling's height and light on architecture. Thirteen allometric variables were regressed to the height of each sapling and the percent of light above the canopy for each species. Statgraphics Plus 4.0 was used.

\section{RESULTS}

\section{Light environment}

The light environment showed a considerable variation (Table 2) Trophis was exposed to a much wider and sunny light environment than Guamia and Pseudolmedia. For Trophis light exposure ranged between 0 to $70.7 \%$ of total above-canopy radiation, while the respective ranges for Guamia and Pseudolmedia were 0 to $37.7 \%$, and 0 to $38.6 \%$. For the three species, individuals between 8 and $15 \%$ of total light corresponded very closely to the intermediate forest structure, while those with values $>15 \%$ corresponded clearly to gaps (Fig. 1). Individuals with the greatest exposure to light occurred in large gaps. Twenty percent of the saplings were in mature forest, $65 \%$ in building phase and $15 \%$ in gaps.

\section{Architecture}

The three species had a significant variation in its architecture depending on the variable (Table 2). Coefficients of variation of the architectural variables ranged from 27 to $141 \%$ in Guamia, 27 to $84 \%$ in Pseudolmedia, and 23 to $137 \%$ in Trophis. This variation results of age and environment effects.

Sapling height had an effect on many architectural variables in the three species (Fig. 2 ). Light had effect only on horizontal crown area in the three species, stem diameter and vertical crown area in Pseudolmedia and Trophis, and cost of leaf support in Guamia. Light affected slightly the vertical crown shading of Pseudolmedia.

As sapling height increased, trunk diameter, horizontal crown area, crown depth, number of leaves, branch length, and vertical crown area, also increased, and the cost of leaf support decrease in the three species. Trunk slenderness decreased and the crown slenderness increased in Guamia and Trophis. In Guamia and Pseudolmedia, inter-branch distance increased, and vertical shading decreased in Pseudolmedia and Trophis (Fig. 2). 

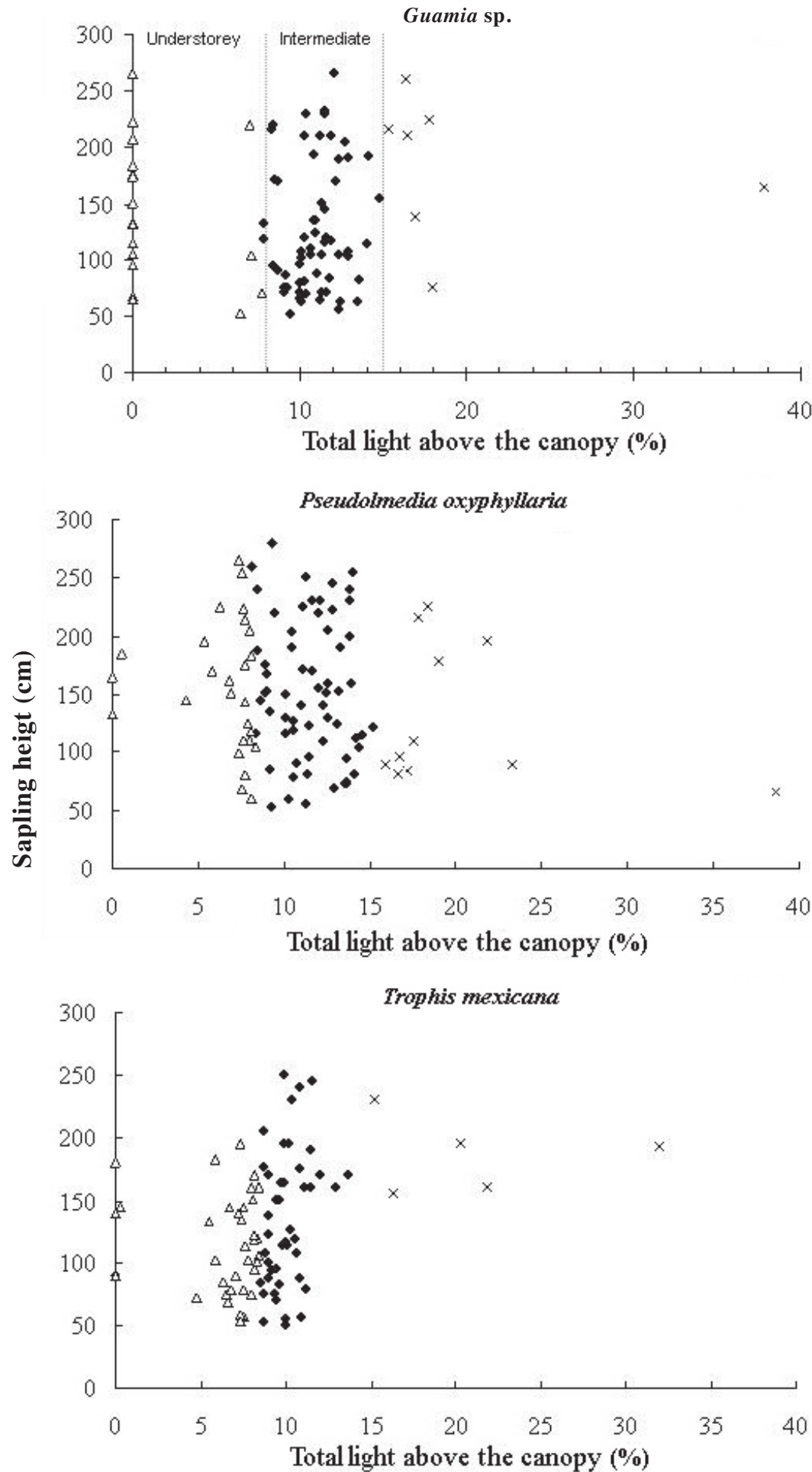

Fig.1: Distribution of tree saplings along the light gradient for the three species selected for the study. The plot shows the intermediate light environment and the two extreme light conditions (understorey and gap) that were used to the architecture analyses in the study. Vertical axis shows saplings height.

Distribución de los árboles juveniles a lo largo del gradiente lumínico de la selva para las tres especies estudiadas. La figura muestra el ambiente lumínico intermedio, así como los dos ambientes extremos de luz (sotobosque y claro) que fueron utilizados en los análisis de arquitectura a lo largo del trabajo. La figura muestra también la altura de los arboles. 

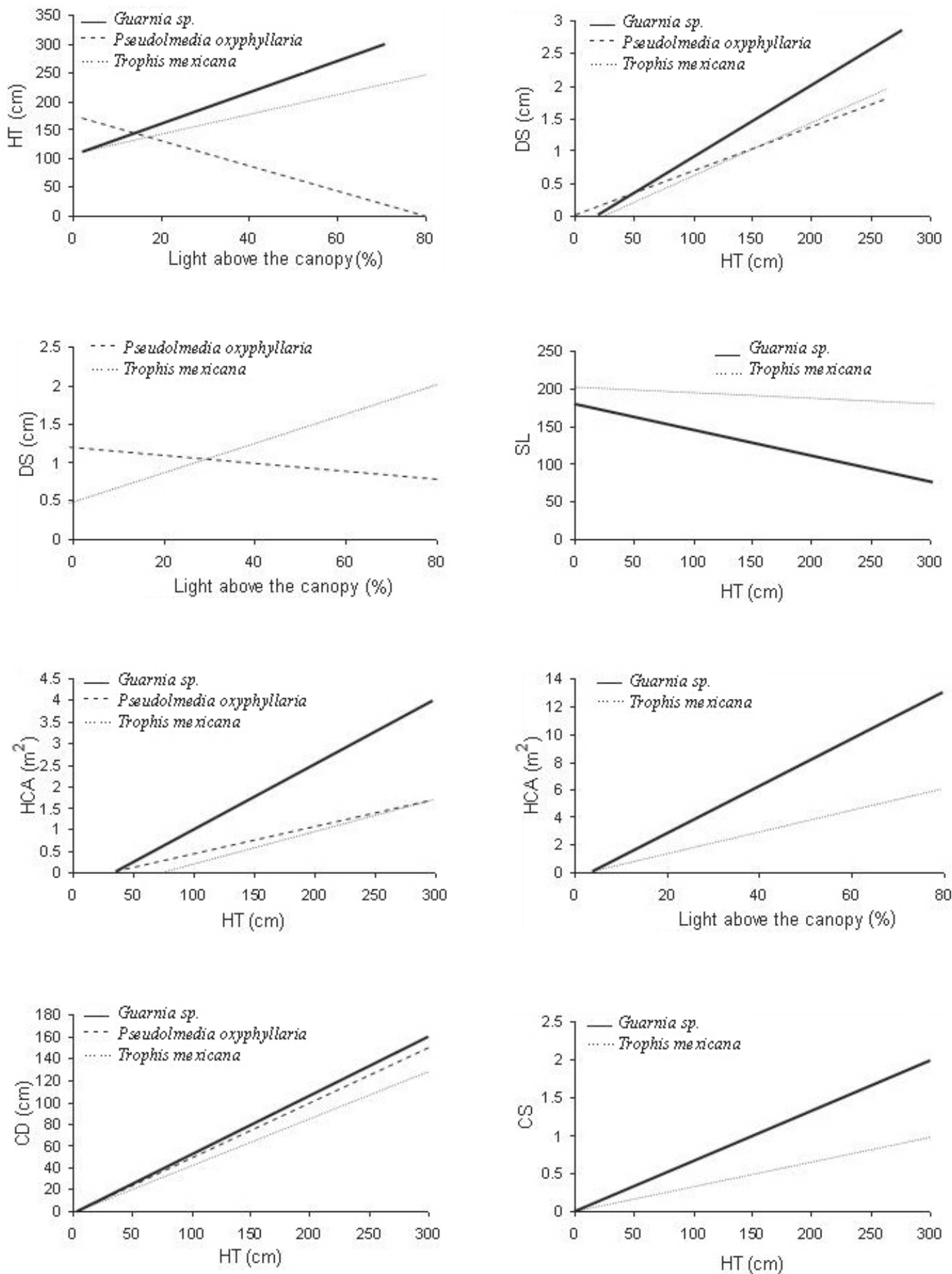

Fig. 2: Separate lines of sapling height and light effects over the architectural variables. Model is a multiple regression analysis of the form: Variable $=\mathrm{a}+\mathrm{b} 1 *$ Height $+\mathrm{b} 2 *$ Light. Only significant results are presented at $\mathrm{P} \leq 0.05$. The slopes show the relative allometric behavior of the species throughout a height range of saplings of $50-300 \mathrm{~cm}$ tall.

Líneas separadas del efecto de la altura de los juveniles y la luz sobre las variables arquitecturales. El modelo es una regresión múltiple de la forma: Variable $=\mathrm{a}+\mathrm{b} 1 *$ Altura $+\mathrm{b} 2 *$ Luz. Se presentan solo los resultados significativos a un valor de $\mathrm{P} \leq 0,05$. La pendiente de las líneas muestra el comportamiento alométrico relativo para las especies a lo largo del intervalo de altura de $50-300 \mathrm{~cm}$. 

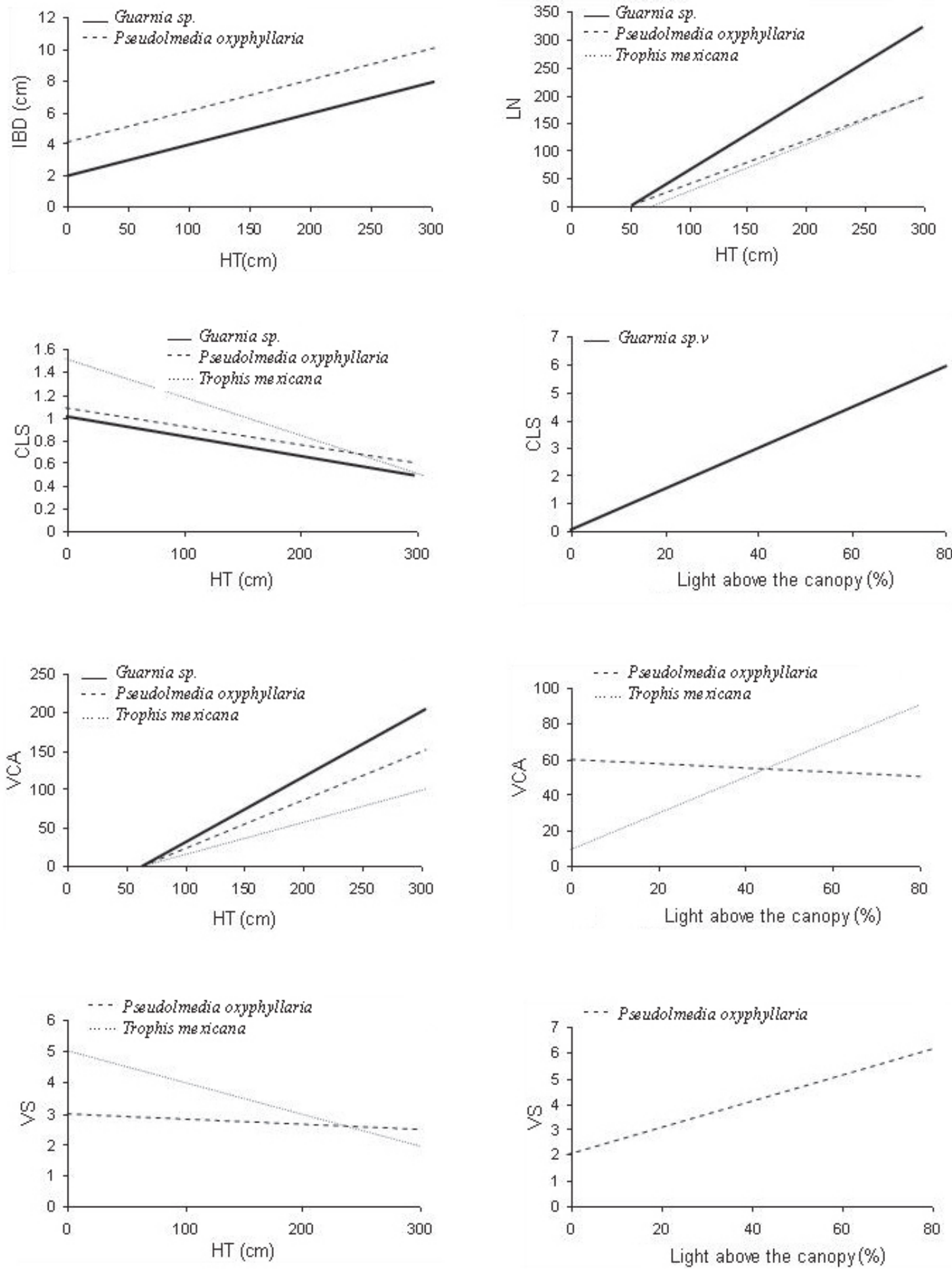

Fig. 2: Continuation. 
There were some differences in the intensity and direction of the response of these traits among the species (Fig. 2). Sapling height increased in Guamia and Trophis as light increased. Short saplings were found in dark environments and tall saplings in the sunny sites. As saplings grow in height, trunk diameter increase more in Guamia than in Trophis and Pseudolmedia, and increased in Trophis and decrease in Pseudolmedia as light increased. Guamia increased more its horizontal crown area than Trophis and Pseudolmedia as sapling height and light increased; Pseudolmedia decrease it as light increased. Guamia increased more the leaves than Trophis and Pseudolmedia as sapling height increased, and Pseudolmedia, slightly decrease it as light increased. The cost of leaf support strikingly increased in Guamia as light increased. As sapling height increase, the vertical crown area increased in the three species, while increased in Trophis and slightly decrease in Pseudolmedia as light increase. Vertical shading decreased in Pseudolmedia and Trophis as sapling height increased, and increased in Pseudolmedia as light increased (Fig. 2). Increment of crown depth was similar for the three species but not for horizontal crown area; Guamia increased more its HCA indicating that Pseudolmedia and Trophis conformed more to slender crown in illuminated sites. However, this crown variation was not reflected in the crown form index (CS).

\section{DISCUSSION}

Various methods, including the PAR photometer, have been used in the analysis of the relationship between architecture and light (King 1991, 1994, King et al. 1997, Bongers \& Sterck 1998, Poorter 1999, Poorter \& Werger 1999, Sterck et al. 1999). Actinometry proved to be an inexpensive method to estimate the light environment in tropical forest, and allowed simultaneous evaluations at different sites. The method works as an integrating light system, as it estimates the total amount of direct and indirect light over a period of time. Owing to these characteristics, the method is useful to detect spatial variability of the light environment where the plants grew with a good precision, but not the temporal variability as the method should be evaluated for long periods of time. Correlation ( $\mathrm{r}$ ) between UV and PAR was 0.92 ; however UV radiation is higher in diffuse light than direct light and hence in densely forested sites than in clear gaps (Flint \& Caldwell 1998). Owing to this, the UV-PAR relationship cannot be linear throughout the variable forest canopy and this may account for some inaccuracy in the estimates.

A light range from 0 to $70 \%$ of above canopy light was studied here showing some significant results. The species studied were widely distributed among the various forest environments, although most individuals were

TABLE 2

Mean values and coefficients of variation for the architectural variables of the three shade-tolerant species

Valores promedio y coeficientes de variación para las variables arquitecturales de las tres especies tolerantes a la sombra

\begin{tabular}{|c|c|c|c|c|c|c|c|}
\hline \multirow[b]{2}{*}{ Variable } & \multirow[b]{2}{*}{ Units } & \multicolumn{2}{|c|}{ Guamia sp. $\mathrm{n}=72$} & \multicolumn{2}{|c|}{$\begin{array}{c}\text { Pseudolmedia } \\
\text { oxyphyllaria } \mathrm{n}=96\end{array}$} & \multicolumn{2}{|c|}{$\begin{array}{c}\text { Trophis mexicana } \\
\mathrm{n}=78\end{array}$} \\
\hline & & Mean & $\mathrm{CV}(\%)$ & Mean & $\mathrm{CV}(\%)$ & Mean & $\mathrm{CV}(\%)$ \\
\hline$\%$ light above canopy & - & 11.06 & 21 & 11.29 & 31 & 10.9 & 39 \\
\hline Sapling height & $\mathrm{cm}$ & 131.66 & 45 & 153.52 & 38 & 122.85 & 33 \\
\hline Horizontal crown area & $\mathrm{m}^{2}$ & 0.78 & 140 & 0.77 & 83 & 0.23 & 136 \\
\hline Crown depth & $\mathrm{cm}$ & 71.92 & 52 & 83.43 & 52 & 60.88 & 49 \\
\hline Crown slenderness & - & 0.79 & 78 & 0.94 & 64 & 0.44 & 113 \\
\hline Number of leaves & - & 120.16 & 89 & 109.64 & 70 & 50.73 & 111 \\
\hline Inter-branch distance & $\mathrm{cm}$ & 5.75 & 39 & 7.52 & 49 & 13.7 & 56 \\
\hline Trunk slenderness & - & 132.91 & 27 & 148.82 & 26 & 170.04 & 23 \\
\hline Horizontal self-shading & - & 231.0 & 69 & 182.0 & 70 & 341.0 & 78 \\
\hline Vertical self-shading & - & 270.0 & 51 & 230.0 & 65 & 350.0 & 102 \\
\hline Cost of leaf support & - & 2.78 & 57 & 3.10 & 51 & 1.29 & 75 \\
\hline
\end{tabular}


found in patches of building phase of the forest (68\%). When analyzing a short light range from 8 to $15 \%$ of above canopy light, Sterck et al. (1999) did not find much relationship for tree saplings. King (1994) found morphological plasticity in response to light within and between species, in a larger light range of 2 to $10-25 \%$ of above canopy light.

Ontogenetic effect (height) was stronger than environmental effect (light) on sapling's architecture. Responses of some architectural traits along the light gradient indicate that there are some differences in the architecture of these shade-tolerant species. The more shade-tolerant species, Guamia and Trophis tended to present architectural characteristics proper of the group and to differ from the less shade-tolerant species Pseudolmedia which presented some characteristics of the fast growing or light demanding species. Guamia and Trophis increased more in trunk diameter and horizontal crown area, whereas Pseudolmedia decrease its vertical crown shading. The cost of leaf support strikingly increased in Guamia as light increased indicating a low response of the photosynthetic area to higher light levels. However the more shade-tolerant species were not strictly shadetolerant because they presented some other characteristics of growth in the presence of light. Examples of these are increment of sapling height and vertical crown area and decrease of vertical crown shading in Trophis.

As previous works (King 1994, Alves \& Santos 2004, Barker et al. 2006), this study shows that a shade tolerant species has not a strict crown architecture, and in contrast they have some level of plasticity. Plasticity in shade-tolerant species indicates that they can make use of higher light levels in the open sites to grow in height and crown (Bongers \& Sterck 1998). The sapling architectures of canopy and subcanopy species need not necessarily be different, but they are likely to be related to the strategies of waiting for growth opportunities under the canopy (Aiba \& Kohyama 1996). For Pseudolmedia the explanation of architectural variability towards a better-lit environment is easier, since this is a mid-canopy species that makes use of higher levels of light to attain this canopy position.

Aiba \& Kohyama (1996) have found crown growth among canopy and subcanopy species, and height growth in understorey species. The extreme architectural types are not necessarily found ever. Aiba \& Kohyama (1997) found crown size to increase with light availability in understorey species as well. King (1990) found the shrub Faramea occidentalis allometrically more similar to canopy species than to understorey species. Barker et al. (2006) found that the more shade-tolerant species had a deeper crown than the less shade-tolerant species. Guamia grew towards an intermediate shape between the narrow and wide crown growth types.

Tree architecture is an important issue for tree growth. Regarding light effect, horizontal crown area was the most plastic and perhaps useful architectural trait for plant's growth. At higher irradiance, horizontal and vertical crown size of saplings, number of leaves, total leaf area, and self-shading increase in most species (King 1994, Sterck et al. 2001, Sterck et al. 2003), and have been found to directly affect their growth and survival, particularly in the Moraceae sapling species Pseudolmedia oxyphyllaria and Trophis mexicana (Sterck et al. 2003). Alternatively, these species may possess effective adaptations at the leaf morphological and physiological levels, as was documented by Bongers \& Popma (1990).

\section{CONCLUSIONS}

The architecture of these shade-tolerant species did not conform to a clear narrow-crown type expected for shade environments, and instead showed variations of the crown architecture depending on the species. The response of the crown architecture regarding the light increment in these shade-tolerant species was different. Species seemed to develop different architectural strategies to grow under the forest canopy, being the crown size the most plastic and perhaps advantageous architectural trait to compete in higher illuminated sites of the forest understorey.

\section{ACKNOWLEDGEMENTS}

We are grateful to two anonymous reviewers for their valuable critique and suggestions to the manuscript, and to Lourens Poorter for his friendly and expert advice. 


\section{LITERATURE CITED}

AIBA S \& T KOHYAMA (1996) Tree species stratification in relation to allometry and demography in a warm-temperate rain forest. Journal of Ecology 2: 207-218.

AIBA S \& T KOHYAMA (1997) Crown architecture and life-history traits of 14 tree species in a warmtemperate rain forest: significance of spatial heterogeneity. Journal of Ecology 5: 611-624.

ALVES LF \& FAM SANTOS (2002) Tree allometry and crown shape of four tree species in Atlantic rain forest, south-east Brazil. Journal of Tropical Ecology 18: 245-260.

BARKER MG, M PINARD \& R NILUS (2006) Allometry and shade tolerance in pole-sized trees of two contrasting dipterocarp species in Sabah, Malaysia. Biotropica 28: 437-440.

BONGERS F \& J POPMA (1990) Leaf dynamics of seedlings of forest species in relation to canopy gaps. Oecologia 82: 122-127.

BONGERS F \& F STERCK (1998) Architecture and development of rainforest trees: Responses to light variation. In: Newbery DM, HHT Prins \& ND Brown (eds) Dynamics of tropical communities: 126-162. Blackwell Science, Oxford, United Kingdom.

BONGERS F, J POPMA, J MEQUE DEL CASTILLO \& J CARABIAS (1988) Structure and floristic composition of the low-land rain forest of Los Tuxtlas, Mexico. Vegetatio 74: 55-80.

BORRELL P (1980) Fotoquímica. El Manual Moderno, México, Distrito Federal. 114 pp.

CHAZDON RL \& N FETCHER (1984) Light environments of tropical forests. In: Medina E, HA Mooney \& C Vazquez-Yanes (eds) Physiological ecology of plants of the wet tropics: 27-36 Dr. W. Junk, The Hague, Holland.

CLEARWATER MJ \& KS GOULD (1995) Leaf orientation and light interception by juvenile Pseudopanax crassifolius(Cunn.) C. Koch in a partially shaded forest environment. Oecologia 104: 363-371.

FLINT SD \& MM CALDWELL (1998) Solar UV-B and visible radiation in tropical forest gaps: measurements partitioning direct and diffuse radiation. Global Change Biology 4: 863-870.

GIVNISH TJ (1988). Adaptation to sun and shade: A whole-plant perspective. Australian Journal of Plant Physiology 15: 63-92.

HILBERT DW \& C MESSIER (1996) Physical stimulation of trees to study the effects of forest light environment, branch type and branch spacing on light interception and transmission. Functional Ecology 10: 777-783.

HORN H (1971) The adaptive geometry of trees. Princeton University Press, Princeton, New Jersey, USA.

IBARRA-MANRÍQUEZ G \& S SINACA-COLÍN (1995) Lista florística de la Estación de Biología Tropical "Los Tuxtlas", Veracruz, México. Revista de Biología Tropical 43: 75-115.

IBARRA-MANRÍQUEZ G \& S SINACA-COLÍN (1996) Estación de Biología Tropical "Los Tuxtlas", Veracruz, México: lista florística comentada (Mimosaceae a Verbenaceae) Revista de Biología Tropical 44: 41-60.

KING DA (1990) Allometry of saplings and understorey trees of a Panamanian forest. Functional Ecology 4: 27-32.
KING DA (1991) Correlations between biomass allocation, relative growth rate and light environment in tropical forest saplings. Functional Ecology 5: 485-492.

KING DA (1994) Influence of light level on the growth and morphology of saplings in a Panamanian forest. American Journal of Botany 81: 948-957.

KING DA, EG LEIGH Jr., R CONDIT, RB FOSTER \& SP HUBBELL (1997) Relationships between branch spacing, growth rate and light in tropical rain forest saplings. Functional Ecology 11: 627-635.

KOHYAMA T (1987) Significance of architecture and allometry in saplings. Functional Ecology 1: 399404.

KOHYAMA T (1991) A functional model describing sapling growth under a tropical forest canopy. Functional Ecology 5: 83-90.

KOHYAMA T \& M HOTTA (1990) Significance of allometry in tropical saplings. Functional Ecology 4: 515-521.

KÜPPERS M (1989) Ecological significance of aboveground and architectural patterns in woody plants: a question of economy-benefit relationships. Tree Physiology 4: 375-379.

MARTÍNEZ-RAMOS M (1985) Claros, ciclos vitales de los tropicales y la regeneración de las selvas altas perennifolias. In: Gómez-Pompa A \& S del Amo (eds) Investigaciones sobre la regeneración de selvas húmedas tropicales en México: 379-393. Alambra, México, Distrito Federal.

MARTÍNEZ-SÁNCHEZ JL (1999) Aspects of tropical rain forest and pasture nutrient dynamics at Los Tuxtlas, Mexico. Ph.D. Dissertation, University of Stirling, Stirling, United Kingdom. 145 pp.

MURRAY NA (1993) Revision of Cymbopetalum and Porcelia (Annonaceae). Systematic Botany Monographs 40: 1-121.

PIERIK RLM (1965). Integrating photochemical light measurment, an ecological study in the Middachten woodland in the Netherlands. Medelingen van de Landbowhogeschool Wageningen 65: 1-19.

POORTER L (1999) Growth responses of 15 rain-forest tree species to a light gradient: the relative importance of morphological and physiological traits. Functional Ecology 13: 396-410.

POORTER L \& MJA WERGER (1999) Light environment, sapling architecture, and leaf display in six rain forest tree species. American Journal of Botany 86: 1464-1473.

POPMA J, F BONGERS \& J MEAVE DEL CASTILLO (1988) Patterns in the vertical structure of the tropical lowland rain forest of Los Tuxtlas, México. Vegetatio 74: 81-91.

STERCK FJ, DB CLARK, DA CLARK \& F BONGERS (1999) Light fluctuations, crown traits, and response delays for tree saplings in a Costa Rican lowland rain forest. Journal of Tropical Ecology 15: 83-95.

STERCK FJ, F BONGERS \& DM NEWBURY (2001) Tree architecture in a Bornean lowland rain forest: intraspecific and interspecific patterns. Plant Ecology 153: 279-292.

STERCK FJ, M MARTÍNEZ-RAMOS, MG DYER-LEAL, J RODRÍGUEZ-VELÁZQUEZ \& L POORTER (2003) The consequences of crown traits for the growth and survival of tree saplings in a Mexican lowland rainforest. Functional Ecology 17: 194200. 
TERBORGH J (1985) The vertical component of plant species diversity in temperate and tropical forests. American Naturalist 126: 760-776.

TURNER IM, WK GONG, JE ONG, JS BUJANG \& T KOHYAMA (1995) The architecture and allometry of mangrove saplings. Functional Ecology 9: 205212 .

WARREN WILSON J (1981) Analysis of light interception by single plant. Annals of Botany 48: 501-505.

Associate Editor: Luis Corcuera

Received June 6, 2006; accepted January 11, 2008 
